\title{
Citation:
}

O'Kelly B.C., Ward P.N. and Raybould M.J. 2008. Stabilisation of a

progressive railway embankment slip, Journal of Geomechanics and

Geoengineering, Vol. 3, No. 4, 231-244.

\section{Stabilisation of a progressive railway embankment slip}

\section{Brendan C. O’Kelly†}

Lecturer in Civil Engineering

Department of Civil, Structural and Environmental Engineering

Museum Building, Trinity College Dublin, Dublin 2, Ireland.

Tel. 00353 16082387, fax. 00353 16773072, E-mail: bokelly@tcd.ie

$\dagger$ formerly Scott Wilson Ltd., Royal Court, Basil Close, Chesterfield, Derbyshire

S41 7SL, UK.

\section{Phillip N. Ward}

Associate (Ground Engineering)

Scott Wilson Ltd., Royal Court, Basil Close, Chesterfield, Derbyshire S41 7SL, UK Tel. 00441246 244667, fax 00441246209229

E-mail: philip.ward@scottwilson.com

\section{Matthew J. Raybould}

Director (Ground Engineering)

Scott Wilson Ltd., Royal Court, Basil Close, Chesterfield, Derbyshire S41 7SL, UK Tel. 00441246 209221, fax 00441246209229

E-mail: matthew.raybould@ scottwilson.com

\section{Corresponding author: Brendan O'Kelly}

First submission: 31st August 2007.

Resubmitted: 11th June 2008. 
Abstract: A walkover survey of a side embankment on the West Coast Mainline railway (UK) revealed significant movement of the twin-track; a waterlogged trackbed and general deterioration of the slope. Ground monitoring and investigations indicated that in addition to shallow washout failures and formation pumping problems at trackbed level, the embankment was at limiting equilibrium with progressive downslope movement occurring along a deep-seated shear zone $\left(\bar{\varphi}_{\text {postpeak }}^{\prime}=22^{\circ}\right)$ within underlying strata of glacial till and laminated clay (weathered mudstone/siltstone). Phreatic level increases during rainstorm events, in combination with winter groundwater maxima, induced artesian pressures on the underside of the steeply-sloping shear zone triggering step increases in shear displacements. Other factors included the gradual post-peak decline in shear strength due to creep; internal weathering; cyclic, transitory stress increases by passing trains and densification of the overlying embankment fill. The upgrade works reduced the hazard of further embankment movement affecting the track and comprised the installation of stabilising piles along the mid embankment-slope arresting the deep-seated slide (factor of safety, FOS =1.2); the construction of an earth buttress and regrading works reducing the upper slope gradient (preventing shallower slips and wash-out failures, FOS $\geq 1.3$ ) and improved site drainage.

Keywords: Embankment; Embedded wall; Pile; Instability; Slope; Stabilise

\section{Introduction}

The Bessie Ghyll embankment site is located along a section of the Lancaster and Carlisle Line on the West Coast Mainline railway (UK) about $1.5 \mathrm{~km}$ southwest of the village of Great Strickland, Cumbria, UK (Figure 1). The railway, which comprises a twin track (Up and Down lines) with $25-\mathrm{kV}$ overhead electrification, has a high line speed of $80 \mathrm{mph}(129 \mathrm{~km} / \mathrm{h})$ and follows a curved radius locally (hence the hazard of a restricted sight distance).

A site walkover survey in December 2000 revealed significant movement and distortion of the track and trackside services and a general deterioration of the embankment slope. Network Rail (the Client) instructed Edmund Nuttall Ltd. (the Contractor) to design and construct the necessary upgrade works which were to be completed without disruption to rail traffic. Scott Wilson Ltd. (the Designer) was appointed by Edmund Nuttall to undertake a desk study, detailed walkover surveys, ground investigations (GIs) and to design the necessary remedial works to limit future track movements along a critical section of the embankment, about $75 \mathrm{~m}$ in length. A timeline for the site walkover surveys, ground monitoring and investigations and engineering works is presented in Table 1. 


\section{Ground conditions}

The ground conditions were established from a search of historical data for the locality; ground monitoring and investigations within the embankment core and site walkover surveys.

\subsection{Desk study}

The affected earthworks were located at UK Ordinance Survey grid reference NY552 214 between mileages 44 miles 531 yards and 44 miles 596 yards along the Lancaster and Carlisle rail line which, locally, was aligned in a general northwestsoutheast direction (Figure 1). Distances and locations along rail lines are traditionally specified in miles and yards in the UK rail industry. Note that one mile equals $1.609 \mathrm{~km}$ and one yard equals $0.914 \mathrm{~m}$. Figure 2 indicates some terminology as applied to the layout of the twin track at the Bessie Ghyll site. The mediumheight embankment, which had been constructed on steeply-sloping and side-long ground, supported the Up-line (east side). The embankment toe was located about $10 \mathrm{~m}$ from the River Leith, which flowed northwards, sub-parallel to the rail line (Figure 1). The M6 National Primary road was located about $200 \mathrm{~m}$ west of the site.

The embankment and twin-track railway are clearly shown, following the present alignment, on the British Ordnance Survey (1875) map. No obvious or significant changes were shown on later maps although the area has had a long history of slope instability. For example, the British Ordnance Survey (1920) map noted that a slip failure had occurred in Sheriff Park (Figure 1), directly north of the Bessie Ghyll site.

The British Geological Survey (1975) map indicated that the site was underlain by a thin covering of glacial drift deposits while the bedrock geology was shown as the Carboniferous Limestone Series, appearing to dip towards the River Leith. The British Geological Memoir (1897) indicated that the bedrock mainly comprised a series of limestone flags (typically thickly bedded and locally altered to dolomite) and sandstones, which were variable in detail and underlain by shales, with the occurrence of thin shale bands likely.

\subsection{Site walkover surveys}

Site walkover surveys in December 2000 revealed that the embankment was between 7.0 and $8.0 \mathrm{~m}$ in height and sloped towards the river at an overall angle of about $30^{\circ}$ to the horizontal (Figure 3(a)). The top section of the embankment slope was covered with shale, cinders, over-spilled ballast and ash material and although mostly bare included some areas of poor vegetation growth (margin maintained clear of rough vegetation/trees to manage leaf fall and tree fall hazards to the tracks). Sparse rough vegetation and tress (many exhibiting distorted trunk growth) lower down the slope had been recently cleared as far as the Network Rail fence- 
line in preparation for the ground monitoring and investigation programme (Figure 3(a) and 4).

The embankment toe had been faced with a dry-stone retaining wall about $1.0 \mathrm{~m}$ in height, and beyond the embankment toe, the natural hillside remained vegetated with dense coniferous forest that extended down to the river. Standing water was observed near the embankment toe and surface springs emerging from the natural ground (soft, wet clayey soil). However, no seepage occurred from the embankment slope itself. Localised exposures of bedrock (reddish brown, fissile, highly and completely weathered mudstones inter-bedded with massively jointed limestone flags and sandstone beds, 0.15 to $0.90 \mathrm{~m}$ in thickness) were observed between the embankment toe and the river. Significant iron staining on the flagstones, which dipped towards the river at an angle of about $15^{\circ}$ to the horizontal, was indicative of chemical weathering in the overlying mudstones (Tomlinson, 2001). The riverbanks were steep, typically between 1.0 and $2.0 \mathrm{~m}$ in height, and comprised outcrop and boulders.

On the Down-line (west side), there was a 6.0 to $7.0 \mathrm{~m}$ deep cutting (Figure 3(b)) with open pastureland present behind the crest. The cutting had also been excavated at an overall gradient of about $30^{\circ}$ to the horizontal and was well vegetated with ground cover further up the cutting. Blocky, limestone outcrops were evident over the lower section of the cutting and a moderate seepage occurred from the exposed rockhead, close to the trackbed level.

The existing surface drainage comprised a diversion ditch near the crest of the cutting and two rubble drains that connected the crest ditch to the Down-cess. The ditch had become blocked, the rubble drains were ineffective and the Down-cess was waterlogged. There was no evidence of any drainage beyond the Down-cess and there were no engineered drainage channels over the embankment slope.

Significant distortion and movement of the track and trackside services and a general deterioration of the embankment slope had occurred. A shallow failure trough was also present along the Up-cess between 44 miles 577 yards and 44 miles 596 yards, which had caused significant snaking of the signalling and telecommunications cable trough (Figure 3(a)). The ground movement in this area had also caused the stanchion that supported the overhead line equipment in the Up-cess to lean by about three degrees to the vertical towards the track (Figure 3(b)). Passing high-speed trains were observed to cause significant vibration of the whole embankment.

\subsection{Ground investigation}

The ground investigation (GI) works had to be carried out sufficiently far away from the track for Green Zone working using compact and lightweight machine plant on the slope. Time constraints in setting up, carrying out the GI works and demobilising combined with the limited and difficult site access meant that a comprehensive GI, 
particularly in close proximity to the track, was not feasible. Instead, the GI works were mainly concentrated over the lower embankment-slope.

The GI works were detailed by Scott Wilson and carried out in two stages by Ritchies Ltd., UK. The first stage was undertaken between February and April 2001 and comprised four number cable-percussion boreholes; six number boreholes using an hydraulic top-drive, tracked-mounted, mini-rotary drill rig (Figure 4); four number exploratory holes to hard stratum using light-weight window sampling techniques and six number trial pits. Four shallow pits were also excavated to locate existing drains in the Down-line cutting. Disused pipes were exposed in two of these pits at about $0.5 \mathrm{~m}$ below ground level (mbgl).

The cable-percussion boreholes included U100 sampling and Standard Penetration tests (SPTs) at $1.0 \mathrm{~m}$ intervals between 1.5 and $5.5 \mathrm{mbgl}$ in the embankment fill; continuous U100 sampling through the deeper superficial deposits to rockhead followed by rotary coring to prove $5.0 \mathrm{~m}$ thickness of bedrock.

The second stage GI works in May 2002 comprised six number rotary-cored boreholes to depths of between 9.0 and $10.0 \mathrm{mbgl}$, targeting the areas along and downslope of the proposed engineering works. Continuous sampling of the superficial deposits (to identify and locate shear planes/zones and obtain undisturbed specimens for laboratory shear strength tests) was followed by rotary coring to determine the quality of the underlying bedrock. Rock cores, nominally $92 \mathrm{~mm}$ in diameter, were recovered using a PWF casing system and triple-lined core barrel. Measurements of total and solid core recovery together with rock quality designation, fracture index and estimated mass strength classifications were made. All boreholes were backfilled with a cement-bentonite grout on completion.

\subsection{Stratigraphy and insitu testing}

The inferred sequence of the strata encountered during the GIs are summarised in Table 2 and are comparable with that reported by the British Geological Memoir and Survey $(1897 ; 1975)$. The embankment core mainly comprised imported, clayey gravel and gravely sand but also included wet pockets of slightly ashy, sandy gravely clay. SPT N-counts of between four and eight blows (no specific trend for increase in $\mathrm{N}$-count with depth) were recorded in the embankment fill indicating that this stratum was in a loose state. Representative peak and residual effective angle of shearing resistance values of $30^{\circ}$ and $28^{\circ}$, respectively, were determined for the granular fill component using empirical correlations reported by Peck et al. (1967).

The firm to stiff glacial till (very silty, sandy, gravely clay with some cobbles) was between 0.5 and $1.7 \mathrm{~m}$ in thickness and locally variable including zones of soft clay. Rockhead was typically located about $4.2 \mathrm{mbgl}$ at mid slope, and the variablyweathered bedrock (Carboniferous Limestone Series) comprised limestone flags (strong) with inter-beds of sandstones (moderately strong) and mudstones and 
siltstones (very weak to weak with poor core recovery). The base of the limestone succession was not encountered but proven in thickness in excess of $5.5 \mathrm{~m}$.

A wet shear zone was identified within the glacial till (described as very soft, very silty, sandy gravely clay) and in the upper $0.2 \mathrm{~m}$ thickness of the laminated clay (completely weathered mudstone with silt dustings on laminae) that was overlying the limestone flags. No SPTs related to the glacial till or laminated clay strata. Back analysis of previous failures indicated that the glacial till and laminated clay deposits are characteristic of the regional geology and generally highly cross-anisotropic which has lead to previous slip failures in the locality as note, for example, on the British Ordnance Survey (1920) map. The glacial till has typical peak and residual effective angle of shearing resistance values of $30-35^{\circ}$ and $20-25^{\circ}$, respectively.

\subsection{Geotechnical laboratory testing}

A suite of geotechnical laboratory classification and shear strength tests was carried out in accordance with BS1377 (1990) and included consolidated-undrained (CU) triaxial compression tests, and with continuous measurement of the pore water pressure response, on fully saturated undisturbed specimens of the glacial till and the pockets of cohesive embankment fill. Shear strength tests could not be carried out on the laminated clay due to its poor core recovery. The cohesive fill was characterised as inorganic, slightly ashy, sandy gravely clay of intermediate plasticity (liquid limit, $w_{l}$ $\cong 40 \%$ and plasticity index, $I_{P} \cong 20$ ).

Sets of three undisturbed test specimens, $75.0 \mathrm{~mm}$ in diameter and nominally $150 \mathrm{~mm}$ in length, were prepared from the borehole cores corresponding to the mid-height of the glacial till and cohesive embankment-fill strata. The specimens were saturated over a period of six days (confirmed by measuring a Skempton (1954) pore pressure coefficient $B \geq 0.96$ ); isotropically consolidated over a period of one day to effective confining stresses, $\sigma_{3}{ }_{3}$ of 75,150 and $300 \mathrm{kPa}$ followed by shearing to failure over a period of one day. The $\sigma_{3}^{\prime}$ range covered the typical range of effective overburden pressures acting at the strata mid-height, beneath the embankment.

Figure 5 shows the peak $s$ ' and $t$ ' values mobilised during the CU triaxial compression tests, where $s^{\prime}$ and $t^{\prime}$ are the effective stress path parameters popularised by Massachusetts Institute of Technology (MIT). In the case of the cohesive fill, the applied $\sigma_{3}^{\prime}$ range exceeded the effective overburden pressure (i.e. normally consolidated specimens) resulting in a peak effective cohesion, $c^{\prime}{ }_{\text {peak }}=0 \mathrm{kPa}$. A peak effective angle of shearing resistance, $\phi_{\text {peak }}^{\prime}=28^{\circ}$ was calculated from the best-fit failure line on the $s^{\prime}-t$ ' plot (Figure 5). In the case of the glacial till, the maximum $\sigma_{3}^{\prime}$ value of $300 \mathrm{kPa}$ was less than the pre-consolidation pressure value (overconsolidation in glacial times) giving rise to $c^{\prime}{ }_{\text {peak }}>0$. Similarly, $c^{\prime}{ }_{\text {peak }}=7 \mathrm{kPa}$ and $\phi_{\text {peak }}^{\prime}=33^{\circ}$ were calculated from the best-fit failure line for the glacial till on the $s^{\prime}-t$ ' plot and these values are consistent with its low plasticity ( $\left.w_{l} \cong 30 \% ; I_{P} \cong 15\right)$ and empirical correlations, giving typical $\phi_{\text {peak }}^{\prime}=30$ to $35^{\circ}$, reported by Kenney (1959). 


\subsection{Monitoring}

\subsubsection{Instrumentation}

The ground instrumentation comprised two-number inclinometers and a single standpipe piezometer, which had been installed in boreholes through the embankment core, and a line of survey pegs located along the Up-cess. Scott Wilson Pavement Engineering (UK) also carried out geophysical and level surveys to monitor the rail movements and trace lateral contrasts in the condition and profile of the trackbed over the length of the site.

\subsubsection{Survey pegs}

A line of six-number survey pegs was installed along the Up-cess (with the leaning stanchion at its mid-point) and the distances between the cess rail, pegs and stanchion were periodically measured between August 1998 and April 2000. Over this period, the embankment crest had moved by between 10 and $20 \mathrm{~mm}$ away from the cess rail in the direction of the river. In addition, the distance between the leaning stanchion in the Up-cess and a secure stanchion (fixed reference) located directly opposite in the Down-cess had increased by about $15 \mathrm{~mm}$, indicating that the Up-cess had moved similarly towards the river.

\subsubsection{Inclinometers}

Two number inclinometers, namely I01 and I02, were installed in the upper embankment-slope (about 4.2 and $6.4 \mathrm{~m}$, respectively, from the near rail on the Upline). The inclinometer boreholes were cored to $11.0 \mathrm{mbgl}$, which provided an embedment of about $5.0 \mathrm{~m}$ in the stable bedrock. Monitoring twice-weekly began in April 2001 and the data are presented as cumulative deflection and displacement versus time plots in Figure 6. Note that a negative deflection reading indicates movement away from the track (down the slope).

Slow and progressive downslope movement had occurred (no reversals in ground movements due to seasonal effects) with sharp inclinometer distortions occurring between 5.2 and $6.2 \mathrm{mbgl}$. Maximum inclinometer deflections of between 36 and 52 $\mathrm{mm}$ were recorded roughly perpendicular to the track between April 2001 and July 2002. Instrument I02 indicated a more clearly defined shear surface whereas instrument $\mathrm{I} 01$ indicated a shear zone of up to $1.0 \mathrm{~m}$ in thickness within the glacial till (very soft, very silty, sandy gravely clay) and thinly laminated clay (completely weathered mudstone/siltstone). The maximum deflection recorded by instrument I02 occurred about 1.5 to $2.0 \mathrm{~m}$ above the shear surface (Figure 6(a, b)) suggesting sympathetic shear displacements in the overlying embankment fill, which was not surprising given its loose state. Both inclinometers indicated negligible movements below rockhead, at about $6.2 \mathrm{mbgl}$. 
The rate of downslope movement (shown in Figure 6(c)) responds to seasonal rainfall patterns and individual rainstorm events. By specifying depth limits for the displacement versus time plots, shear zones affecting the installation can be isolated and movement measured separately. For example, the 5.2-6.2 $\mathrm{m}$ plot in Figure 6(c) shows the relative movements of the inclinometer tubes across the shear zone (between 5.2 and $6.2 \mathrm{mbgl}$ ). Similarly, the $0.2-11.2 \mathrm{~m}$ plot shows the movement of the top of the tube relative to the bottom of the tube (secured in stable bedrock). The rates of movement measured along the shear zone accelerated from typically 0.03$0.04 \mathrm{~mm} /$ day (averaged over 284 days) up to $0.85 \mathrm{~mm} /$ day (averaged over 31 days) due the wet season of November to March. Step increases of about 8 and $27 \mathrm{~mm}$ in the displacement measured along the shear zone occurred during prolonged periods of inclement weather between mid September and mid October (2001) and mid January to the end of February (2002), respectively.

\subsubsection{Groundwater}

Groundwater is often the most important triggering factor in landslide events. The groundwater level in the standpipe-piezometer, which was located beneath the upper embankment-slope, was periodically monitored between April 2001 and November 2002. The limited data indicated a relatively stable phreatic level about $1.9 \mathrm{~m}$ below the shear zone, within the limestone flags. Groundwater strikes recorded during the second stage GI (May 2002) indicated that at mid-slope, the groundwater table was located within the shear zone. Beyond the embankment toe, the groundwater table was coincident with the natural ground surface (surface springs indicating artesian conditions). However, the piezometer monitoring frequency was insufficient (weekly during the months of April and May (2001) and then monthly until November 2002) and it is postulated that rapid, transient increases in the phreatic levels occur during rainstorm events, particularly during the wet season (November to March).

The steeply sloping and relatively impermeable shear zone (glacial till and laminated clay) separated the more permeable embankment fill and underlying bedrock (artesian aquifer). Rainstorm events, in particular during the winter groundwater maxima, can rapidly induce artesian pressures on the underside of the shear zone (especially beneath the lower slope) as well as increasing its degree of saturation further up the slope. The relatively free-draining embankment fill stratum was generally in a moist condition and its poor vegetation cover allowed significant rainfall infiltration to occur.

\subsubsection{Geophysical testing}

A trolley-mounted, ground probing radar survey of the trackbed and cess-widths was carried out to a depth of about $1.0 \mathrm{mbgl}$ along five survey lines between February and March, 2001. The Up-line trace indicated consistently deep and goodquality ballast beneath the Up-line although the ballast layer was significantly 
thicker between 44 miles 561 yards and 44 miles 583 yards, which was most likely due to regrading of the trackbed following earlier subsidence along the embankment crest. The Down-line trace indicated a clean and thick ballast layer beneath the Down-line.

However, the Six-foot trace indicated that the strip of trackbed between the Up and Down-lines was in a poorer condition and a shallow interface between 44 miles 462 yards and 44 miles 616 yards was indicative of a dirty ballast. The Down-cess trace indicated a very variable interface depth (indicative of a well established formation pumping problem) between $44 \mathrm{~m} 528$ yards and $44 \mathrm{~m} 570$ yards and was consistent with the waterlogged Down-cess observed during the walkover surveys.

\subsubsection{Track monitoring}

Monitoring of the Up and Down-line track levels (including measurement of the cant, cant gradient and Six-foot width) commenced in November 2001. Cant is the difference in elevation between the rails and the cant gradient is the difference in cant measurements taken over a $3.0 \mathrm{~m}$ length along the track (e.g. a $5.0 \mathrm{~mm}$ difference corresponds to a cant gradient of $3,000 / 5$ or 1 in 600). A settlement trough was identified along the Up-line between 44 miles 538 yards and 44 miles 593 yards.

Significant increases in cant and cant gradient during May 2002 coincided with the second stage GI works that were carried out over the lower embankment-slope. Ongoing slope movements caused a drop in the levels of both lines (Up $11.0 \mathrm{~mm}$ max and Down $7.0 \mathrm{~mm}$ max) and was followed by a further $7.0 \mathrm{~mm}$ max drop in the Upline over the following two-day period. Urgent remedial works (lift, pack and tamp cess rail on the Up-line) had to be undertaken in early June 2002 to reduced the cant gradient from greater than 1:200 to less than 1:500.

\section{Ground model and design parameter values}

\subsection{Ground model}

The embankment profile was accurately determined from a topographical survey carried out by Interactive Track Services Ltd. (UK) in December 2000. Figure 7 shows a cross-section through the critical area of the embankment. The stratigraphy was based on the GI data, which are summarised in Table 2. The phreatic surface was positioned near the base of the embankment fill simulating raised phreatic levels during a prolonged rainstorm event.

\subsection{Inferred failure mechanisms}

From the site observations and monitoring data, it was evident that the embankment had critical local and global slope instability problems. Inadequate drainage over the 
cutting slope and Down-cess had caused shallow wash-out failures and formation pumping problems along the Up and Down-cess, respectively, and some loss of ground support beneath the sleepers on the Up-line which had affected the track performance. The wash-out failures had also instigated a series of shallow slips in the over steepened slope near the crest (slope gradient approximately equalled natural angle of repose of loose granular fill) causing the stanchion tilting.

The entire embankment was progressively moving downslope (limiting equilibrium) along a deep-seated, non-circular shear zone within the glacial till and thinly laminated clay (completely weather mudstone/siltstone). The crown of the rotational slide was located near the toe of the Down-line cutting with the shear zone daylighting through the glacial till just beyond the embankment toe. The location and profile of the shear zone was confirmed from inspection of the inclinometer data and recovered borehole cores.

Rapid, transient increases in artesian pressures on the underside of the shear zone during prolonged rainstorm events, particularly during the winter groundwater maxima, were the main triggers in accelerating ground movements along the shear zone. Numerous data sets (for example, O'Kelly et al. (2006; 2008); Hodgetts et al. (2007)) have shown correlation between rainfall and slide movement. Other contributing factors included progressive creep movement and artificial vibrations (cyclic and transitory stress increases by high-speed trains) causing further remoulding of the material in the shear zone (post peak decline of shear strength) and internal weathering, particularly of the underlying mudstones/siltstone. Ground vibration from the passing trains also caused densification of the loose embankment fill which contributed to the settlement response at track level.

\subsection{Design parameter values}

The available strength data for the shear zone were limited to the driller's description and inspections of the rock cores (poor recovery). Hence, an effective stress backanalysis of the critical embankment section (Figure 7) was carried out to determine representative shear strength parameter values for design. The critical section was analysed in plane strain using Geosolve SLOPEIW and the method of slice equilibrium after Morgenstern and Price (1965), assuming the limiting equilibrium condition (factor of safety, FOS = 1.0). The input values for the embankment fill and glacial till strata were based on the insitu and geotechnical laboratory test data. A sensitivity check was also carried out for lower phreatic levels since high phreatic levels are unconservative for the purpose of back analysing the shear strength parameter values.

A design $\bar{\varphi}_{\text {postpeak }}^{\prime}=22^{\circ}$ was determined for the shear zone. Note that this is an intermediate value between the peak (CU triaxial compression value of $33^{\circ}$ ) and the residual condition. Back analysis of other structures suggests that large ground movements can occur, and are sufficient to lead to a serviceability failure (as at the 
Bessie Ghyll site), with the mean shear strength varying from the peak to residual values along the shear surface.

\section{Design of remedial engineering works}

\subsection{Solutions considered}

Best practice measures were selected through a process of value engineering to reduce the hazard of future embankment movement affecting the track and trackside services. The main options considered included:

- Drainage.

- Soil nail the embankment slope.

- Reprofile the slope and construct a berm or gabion retaining wall to support the embankment toe.

- Stabilise the landslip using slender piles, bored through the sliding mass, and penetrating the underlying stable ground.

An improved drainage scheme, including counterfort drains over the embankment slope is particularly suitable and usually very effective in cases with a high groundwater table. However, the water table was at a significant depth within the Bessie Ghyll embankment and the risk of a slope failure occurring during the excavation of a deep drainage trench by machine plant on the slope was too high. Moreover, the necessary improvements in the overall FOS against slope instability could not be achieved by drainage alone (typically achieve $10 \%$ improvement in FOS, concentrated in the vicinity of the drains). Counterfort drains were, however, used to improve the FOS on the cutting slope.

The soil nail option was discounted due to the loose state of the embankment fill and some uncertainty about the rockhead depth and profile, particularly beneath the upper embankment slope, which caused concerns as to the ability of the scheme to adequately resist the slope movement. The toe-berm option was discounted due to the requirement to purchase adjoining land; the major fill import necessary and difficult site access (close proximity of the River Leith). A gabion retaining wall located at the embankment toe could not generate sufficient toe-weight to stabilise the slip.

The installation of stabilising piles (shear dowels) along the embankment crest was discounted due to the close proximity of the engineering works to the Up-line (possession of all or part of the track was not possible) and the likelihood of ongoing and destabilising ground movements continuing to occur further down the embankment slope. The preferred solution comprised a combination of these options, namely the installation of stabilising piles along the mid-slope of the embankment followed by the construction of an earth buttress and regrading works to reduce the upper slope gradient as well as an improved drainage scheme (Figure 8). 
The deep-seated rotational slide was stabilised by two rows of vertical, reinforcedconcrete piles. The earth buttress was supported by a $2.0 \mathrm{~m}$ high, gabion wall that was founded on a shallow granular foundation, centred above the pile rows (adding toe weight). The front of the gabion wall was located $16 \mathrm{~m}$ downslope from the nearest rail. The spatial arrangement of the piles was designed to generate some portal frame action without the concrete piles significantly altering the groundwater flow downslope. The regrading works reduced the upper slope gradient from about $30^{\circ}$ (one vertical in 1.7 horizontal) to one in three. The Up-cess was also extended to 2.8 $\mathrm{m}$ in width along the repair area.

\subsection{Design methodology}

\subsubsection{FOS against slope instability}

The earthworks design was in accordance with the general recommendations of BS6031 (1981) to achieve a FOS $\geq 1.2$ for the existing deep-seated rotational slide and a FOS $\geq 1.3$ for other potential slides and shallower slips day lighting just upslope of the gabion wall. The upgraded embankment in Figure 9 was analysed again using SLOPEIW to determine the additional horizontal force that the stabilising piles must be capable of exerting up along the shear zone.

The effective stress analysis employed the design shear strength parameter values listed in Table 3 and with a surcharge of $50 \mathrm{kPa}$ applied along the twin track. The long-term stability relied on the shearing resistance only (i.e. peak effective cohesion, $\mathrm{c}_{\text {peak }}=7 \mathrm{kPa}$ determined from the $\mathrm{CU}$ triaxial compression tests on the glacial till was not used in the design calculations) since the shear zone included part of the glacial till stratum. The soil mass between the pile rows was assumed to behave as a semi-rigid body and although discrete, the pile rows were analysed as a continuous wall since the centre spacing between adjacent piles was less than three pile diameters (arching effects). The horizontal force that the pile wall must be capable of supplying was assumed to act at the mid-height of the $1.0 \mathrm{~m}$ thick, shear zone.

The analysis indicated that the pile wall solution was particularly sensitive to the depth and profile of the shear zone, particularly beneath the lower embankment slope. Hence, the reason for carrying out the GI in two stages with the second stage specifically targeting the areas in the vicinity and downslope of the pile wall. Slight variations in the input values for the soil strata above the shear zone were less critical.

A sensitivity study was carried out in which two scenarios were considered, namely: a most probable embedment of $4.0 \mathrm{~m}$ from the underside of the gabion wall to rockhead (Figure 9) and a pile embedment of $5.0 \mathrm{~m}$, which corresponded to the most unfavourable ground conditions expected. The ground model for the $5.0 \mathrm{~m}$ embedment was the same as that shown in Figure 9 except that the rockhead depth was located a distance of $1.0 \mathrm{~m}$ lower. 
The analysis indicated that the pile wall must be capable of supplying horizontal forces of 85 and $100 \mathrm{kN} / \mathrm{m}$-run for the most probable and most unfavourable ground conditions, respectively, to increase the FOS value along the existing shear zone from unity to 1.2. Other potential rotational slides, including compound slips incorporating part of the shear zone, and shallow slips day-lighting just upslope of the gabion wall had FOS > 1.3. Further SLOPEIW analysis indicated that the FOS value for the temporary works condition (piling rig operating on a working platform near the mid slope) was satisfactory.

\subsubsection{Gabion wall design}

The $2.0 \mathrm{~m}$ high, gabion wall was founded on a shallow, compacted granular foundation, centred directly above the pile rows. The ultimate bearing capacity of the embankment fill, which supported the gabion foundation, was assessed using the limit equilibrium method and Brinch Hansen factor values (see, for example, Tomlinson, 2001).

The embankment fill stratum supported the dead weight of the box gabion units and also resisted the active earth pressure against the back of the gabion wall, which had a sloping backfill. The resultant vertical and horizontal forces of 154 and $67 \mathrm{kN} / \mathrm{m}$-run, respectively, were adequately resisted in bearing capacity by the earth foundation.

\subsubsection{Stabilising pile wall design}

The stabilising piles $(0.45 \mathrm{~m}$ in diameter and $7.0 \mathrm{~m}$ in length) were aligned in two rows, set a distance of $1.0 \mathrm{~m}$ apart. The piles in each row had a centre spacing of $2.0 \mathrm{~m}$ with alternate piles staggered in plan arrangement. The pileheads were located $0.3 \mathrm{~m}$ below the base of the gabion wall. Hence, the effective pile lengths above and below the mid-height of the shear zone were 4.7 and $2.3 \mathrm{~m}$, respectively, for the most unfavourable ground conditions expected (Figure 10).

The length and spatial arrangement of the piles were determined from a total stress analysis of the shear force that a single pile can receive from the sliding soil mass and transmit to the underlying stable ground. The limit equilibrium method of analysis for a two-layer cohesive soil after Viggiani (1981), and subsequently amended by Chmoulian (2004), was used.

The simplified ground model and the system of forces that a single pile must be capable of resisting are shown in Figure 10(a). Unstable ground (4.0 and $5.0 \mathrm{~m}$ in thickness for the most probable and most unfavourable conditions, respectively) overlies the stable ground of the Carboniferous Limestone Series bedrock. Representative undrained shear strength $\left(\bar{s}_{u}\right)$ values of 100 and $300 \mathrm{kPa}$ were determined from unconsolidated undrained triaxial compression and insitu test data for the upper and lower layers, respectively. The SLOPEIW analysis had indicated that 
the necessary increase in the FOS value against slope instability was achieved by applying a horizontal force of $100 \mathrm{kN} / \mathrm{m}$-run up along the shear zone.

The active earth pressure against the back of the gabion wall and the deadweight of the gabion units are gradually redistributed from the gabion foundation to the pileheads in the longer term due to the ongoing settlement of the loose embankment fill stratum. The pileheads along the inner and outer rows must resist the same horizontal force of $67 \mathrm{kN} / \mathrm{m}$-run but different vertical forces of 63 and $91 \mathrm{kN} / \mathrm{m}$-run, respectively, due to the load eccentricity on the gabion foundation. Further analysis indicated that the uptake of the vertical load component by the pileheads, in addition to the development of some negative skin friction along the pile shaft, enhanced the lateral load carrying capacity of the piles.

Figure 10(b) shows the critical failure mechanism, namely Viggiani (1981) mode B, with the ground simultaneously failing above and below the shear zone. The pile undergoes a rigid rotation since the maximum bending moment acting on the pile section is significantly lower than its yield moment of $285 \mathrm{kN}$.m. The ultimate horizontal forces that the stabilising pile can exert along the shear zone are 288 and $276 \mathrm{kN} / \mathrm{m}$-run for the most probable and most unfavourable ground conditions, respectively. Hence, the most probable FOS values on the ultimate lateral load capacity of the stabilising piles were 3.4 and 1.9 for the short and longer-term conditions, respectively. The corresponding FOS values for the most unfavourable ground conditions were slightly lower at 2.8 and 1.7 .

The pile section was designed in accordance with BS5400 (1988) to resist the system of working loads and bending moments, and for a design life of 120 years. The maximum bending moment acting on the piles was $79 \mathrm{kN} . \mathrm{m}$ in the underlying stable ground. The minimum FOS value of 1.7 (longer term and most unfavourable ground conditions) for the geotechnical design was slightly greater than the load factors (FOS $=1.65$ ) applied for the structural design of the pile.

\subsection{Drainage scheme}

The drainage scheme, which was designed to accommodate a one in 100 year local storm event, collected the runoff and near-surface groundwater from the cutting and embankment slopes and discharged via an outlet headwall to the River Leith. The risk of floodwater causing significant riverbank erosion and impacting on the longterm stability of the embankment was highly unlikely (steep riverbanks of outcrop and boulders).

\section{Construction}

\subsection{Site access}


The upgrade works were constructed between July and October (2002) from mileages 44 miles 524 yards to 44 miles 606 yards, which provided a short overrun on both sides of the failure trough. A temporary access to the embankment toe was built across the river and contamination control measures were implemented, as requested by the UK Environmental Agency.

The existing dry stone wall along the embankment toe was removed and a temporary stoned haul-road constructed from the base of the slope to provide access to the piling platform, located a distance of $1.3 \mathrm{~m}$ above the pile cut-off level (Figure 11(a)).

\subsection{Piling works}

The embankment slope was cut back in bays at about $45^{\circ}$ to the vertical in order to facilitate the progress of the piling works (Figure 11(b)). The sequence in which the piles were installed over the length of the site minimised the potential for excessive slope movements during the works. The pile cavities were formed by auger through the superficial deposits and advanced below rockhead to the full embedment depth (i.e. not to a set penetration in any specific stratum) by percussive down-the-hole drilling.

In some cases, high water ingress occurred during drilling of the final $0.3 \mathrm{~m}$ depth to pile toe level. Balls of clay formed from the cored laminated clay/mudstone bands and adhered to the drill string, blocking off the flush return from the drill bit at the base of the borehole. Hence, the toe level of some of the piles was raised by $0.3 \mathrm{~m}$ (effective pile length of $6.7 \mathrm{~m}$ ) due to concerns that the borehole surface within the bedrock would become coated with the soft remoulded clay, thereby reducing the cast diameter and ultimate load carrying capacity of the pile.

The piles were cast by tremie using a $40 \mathrm{~N} / \mathrm{mm}^{2}$ sulphate-resistant concrete mix and with $50 \mathrm{~mm}$ cover provided to the steel reinforcement links. Integrity testing indicated that all of the piles were structurally sound and the pileheads were subsequently excavated and cut down to the required level (Figure 11(b)).

\subsection{Gabion retaining wall and slope regrading}

The $2.0 \mathrm{~m}$ high, gabion wall was constructed using standard box units $(1.0 \mathrm{x} 1.0 \mathrm{x} 2.0$ $\mathrm{m})$, which were placed on the $300 \mathrm{~mm}$ deep, compacted granular foundation, centred directly above the pile rows. The void behind the gabion wall was backfilled with granular fill.

The upper slope was benched (Figure 11(c)) and backfilled, compacted and regraded with more granular fill, reducing the slope gradient to one vertical in three horizontal (Figure 11(d)). The granular fill was separated from the underlying embankment fill by a geotextile layer. The lower slope was then trimmed to the design profile (Figure 11(e)). Biodegradable jute mesh and seeding placed over the upper slope provided 
erosion protection and the rapid establishment of grass vegetation cover, which reduced rainfall infiltration.

\subsection{Subsurface drainage}

A shallow filter-drain (French drain) was constructed along the line of the existing ditch, set a distance of $2.0 \mathrm{~m}$ back from the crest (Figure 11(f)) to intercept runoff from the pastureland that sloped onto the cutting. Counterfort drains, which replaced the existing rubble drains on the cutting slope, connected the crest drain to a newly constructed Down-cess drain, which intercepted and discharged groundwater and seepages away from the embankment foundation. A subsurface filter-drain, installed behind the gabion wall (Figure 11(c)), intercepted the runoff from the upper embankment slope. The new outfall-headwall was located along the existing line of the riverbank, with the construction works taking place behind a bund, at low stage, during the summer months.

\subsection{Track and ground responses during and after construction}

Monitoring of the two-number inclinometers and track levels continued twiceweekly during the construction period (July to October, 2002). The inclinometer data indicated that no downslope movement had occurred during construction (Figure 12(a)) and that by the end of August 2002 (with stabilising piles installed), the historical displacement at depth had been fully arrested. The inclinometer data also indicated that ground movements of up to $9.0 \mathrm{~mm}$ had occurred back up the slope over a depth of up to $2.5 \mathrm{mbgl}$ during September 2002 due to the regrading works (stress relaxation) over the upper slope.

Drops in the track levels occurred over the full length of the site between August and mid September (2002) and resulted in significant increases in cant between 44 miles 577 yards and 44 miles 596 yards. It is postulated that the recorded track settlements, particularly in the case of the Up-line cess rail, mainly occurred due to the densification of the loose embankment fill by vibrations caused by machine plant operating on the slope. In particular, the drops in both track levels (Up $8.0 \mathrm{~mm}$ max and Down $5.0 \mathrm{~mm}$ max) between mid July and the end of August coincided with the piling works. A further drop in the Up-line (10.0 mm max) between early and mid September coincided with the construction of the gabion wall and slope regrading. Although the cant and cant gradient values were still acceptable, remedial works (lift, pack and tamp ballast) were undertaken during mid September (2002) in order to limit future settlement of the tracks.

Post-construction monitoring of the inclinometers and track levels continued but at a reduced frequency until December 2004 and February 2003, respectively. The monitoring data indicated that the remedial works were fully effective in stabilising the upper embankment-slope (Figure 12(b)), thereby limiting future track 
settlements. The inclinometer data also indicated that no seasonal reversals in the ground movements occurred over the two-year post-construction monitoring period.

\section{Summary and conclusions}

The Bessie Ghyll slope stabilisation highlights some of the main challenges, operational constraints and practicalities in carrying out ground engineering works in close proximity to a mainline railway. The ground monitoring and investigations indicated that in addition to shallow washout failures and formation pumping problems at trackbed level, progressive downslope movement of the side embankment was occurring along a deep-seated, non-circular shear zone within the underlying strata of glacial till and thinly laminated clay (completely weathered mudstone/siltstone).

Phreatic level increases during rainstorm events, particularly in combination with winter groundwater maxima, induced artesian pressures on the underside of the steeply-sloping shear zone triggering step increases in the shear displacements. Other factors included the gradual post-peak decline in shear strength due to (i) progressive creep movements; (ii) cyclic, transitory stress increases by passing high-speed trains and (iii) internal weathering. Densification due to the artificial ground vibrations and sympathetic shear displacements in the overlying embankment fill also contributed to the settlement response. A representative effective angle of shearing resistance, $\bar{\varphi}_{\text {postpeak }}^{\prime}=22^{\circ}$ was determined for the wet shear zone from a back-analysis of the critical embankment section, assumed at limiting equilibrium.

The upgrade works comprised the installation of stabilising piles (shear dowels) along the mid embankment-slope to arrest the deep-seated rotational slide; the construction of an earth buttress and regrading works to reduce the upper slope gradient (thereby preventing shallower slips and wash-out failures) and improved drainage of the site area. The earth buttress was supported by a gabion wall that was founded on a shallow granular foundation, centred directly above the pileheads (adding toe weight), with the front of the wall located $16 \mathrm{~m}$ downslope from the nearest rail (facilitating Green Zone working).

The stabilising piles provided the necessary horizontal force to increase the factor of safety (FOS) value against slope instability along the shear zone from unity to 1.2, as well as providing a FOS $\geq 1.3$ for other potential rotational slides. The length and arrangement of the piles (aligned in two rows and staggered in plan) were determined using the Viggiani limit-equilibrium method of analysis for a two-layer cohesive soil and included sensitivity studies that considered the most probable and most unfavourable ground conditions; alternative phreatic levels and the effects of structural load redistribution in the longer term. The reinforced-concrete piles were cast by tremie to the base of the $0.45 \mathrm{~m}$ diameter cavities that had been augered through the superficial deposits, and advanced below rockhead by percussive downthe-hole drilling. 
Twice-weekly monitoring of the inclinometers and track levels confirmed the appropriateness and sequencing of the engineering works (negligible downslope movements occurred during construction). Shallow ground movements of the upper embankment-slope occurred back towards the track due to some stress relaxation that had occurred during slope regrading. Post-construction monitoring over a two-year period confirmed the effectiveness of the remedial works in fully arresting the historical, deep-seated movement of the embankment.

\section{Acknowledgements}

The authors would like to acknowledge the close collaboration with Edmund Nuttall Ltd. in the successful completion of this project. Network Rail is acknowledged for granting permission to publish this case study. A special word of thanks to David M. Green for assistance in compiling the monitoring data. The paper was written by the lead author while on sabbatical leave at the Urban Institute Ireland, University College Dublin.

\section{References}

British Geological Survey, 1975. Appleby (Solid and Drift). Sheet E30, 1:50,000 scale.

British Geological Memoir, 1897. Appleby, Ulleswater and Haweswater. Sheet 30.

British Ordnance Survey, 1875. Topographic map. 25 inch to one mile scale.

British Ordnance Survey, 1920. Topographic map. Six inch to one mile scale.

BS1377, 1990. Methods of test for soils for civil engineering purposes, Part 8: Shear strength tests (effective stress). British Standards Institution: London.

BS5400, 1988. Steel, concrete and composite bridges. British Standards Institution: London.

BS6031, 1981. Code of practice for earthworks. British Standards Institution: London.

Chmoulian, A.Y., 2004. Analysis of piled stabilisation of landslides. Proceedings of the Institution of Civil Engineers: Geotechnical Engineering, 157 (GE2), 55-56.

Hodgetts, S.J., O'Kelly, B.C. and Raybould, M.J., 2007. Stabilisation of the Stanton Lees landslip using an embedded pile retaining wall. Geotechnical and Geological Engineering, 25 (6), 705-715. 
Kenney, T.C., 1959. Discussion. Journal of the Soil Mechanics and Foundation Engineering Division-ASCE, 85 (SM3), 67-79.

Morgenstern, N.R. and Price, V.E., 1965. The analysis of the stability of general slip surfaces. Géotechnique, 15(1), 79-93.

O'Kelly, B.C., Hodgetts, S.J. and Leung, T.H.F., 2006. Stabilisation of Stanton Lees landslip using pile retaining wall solution. In: Proceedings of the 3rd National Symposium on Bridge and Infrastructure Research in Ireland, Dublin, 1, 233-242.

O'Kelly, B.C., Ward, P.N. and Raybould, M.J., 2008. Slope stabilization of an embankment on the West Coast Main Line, UK. In: Proceedings of the 1st International Conference on Transportation Geotechnics, Nottingham, UK (in press).

Peck, R.B., Hanson, W.E. and Thornburn, T.H., 1967. Foundation Engineering, 2nd edition. John Wiley: New York.

Skempton, A.W., 1954. The pore pressure coefficients A and B. Géotechnique, 4, $143-147$.

Tomlinson, M.J., 2001. Foundation Design and Construction, 7th edition. Prentice Hall: Harlow, England.

Viggiani, C., 1981. Ultimate lateral load on piles used to stabilise landslides. In: Proceedings of the 10th International Conference on Soil Mechanics and Foundation Engineering, Stockholm, 3, 550-560. 
Table 1. Timeline for Bessie Ghyll works.

\begin{tabular}{|c|c|c|}
\hline \multicolumn{2}{|l|}{ Activity } & Timeline \\
\hline \multicolumn{2}{|c|}{ Walkover surveys } & December 2000 \\
\hline \multicolumn{2}{|c|}{ Topographical survey } & December 2000 \\
\hline \multicolumn{2}{|c|}{ Ground investigation (first stage) } & February to April, 2001 \\
\hline & Survey pegs (x 6) & August 1998 to April 2000 \\
\hline \multirow{4}{*}{$\begin{array}{l}\text { Ground } \\
\text { monitoring }\end{array}$} & Inclinometers (x 2) & April 2001 to December 2004 \\
\hline & Standpipe piezometer ( $\times 1$ ) & April 2001 to November 2002 \\
\hline & Geophysical surveys & February to March, 2001 \\
\hline & Track levels and distortion & November 2001 to February 2003 \\
\hline \multicolumn{2}{|c|}{ Ground investigation (second stage) } & May 2002 \\
\hline \multirow{2}{*}{\multicolumn{2}{|c|}{ Construction of remedial works }} & July to October, 2002 \\
\hline & Post-construction quality audit & October 2002 \\
\hline
\end{tabular}

Table 2. Site stratigraphy.

\begin{tabular}{|c|c|c|}
\hline Thickness (m) & Stratum & Description \\
\hline 0.3 to 0.7 & Made ground: Ballast & Loose, sandy, medium to coarse gravel. \\
\hline 1.0 to 5.5 & $\begin{array}{l}\text { Made ground: } \\
\text { Embankment fill }\end{array}$ & $\begin{array}{l}\text { Moist, loose, silty, clayey gravel and gravely sand. Includes pockets } \\
\text { of wet, soft and firm, slightly ashy, sandy gravely clay. }\end{array}$ \\
\hline 0.5 to 1.7 & Glacial till & $\begin{array}{l}\text { Firm to stiff, very silty, sandy, gravely clay with some cobbles of } \\
\text { predominantly Carboniferous limestone and sandstone. }\end{array}$ \\
\hline \multirow[b]{2}{*}{0.5 to 1.0} & \multirow[b]{2}{*}{$\begin{array}{l}\text { SHEAR } \\
\text { ZONE }\end{array}$} & Wet, very soft, red-brown, very silty, sandy, gravely clay. \\
\hline & & $\begin{array}{l}\text { Wet, completely weathered, thinly laminated mudstone with fine } \\
\text { silt dustings on lamina (very weak and weak). }\end{array}$ \\
\hline Not proven & $\begin{array}{l}\text { Carboniferous Limestone } \\
\text { Series }\end{array}$ & $\begin{array}{l}\text { Very weak and weak, friable, thinly laminated mudstone/siltstone } \\
\text { beds (typically } 0.6 \text { to } 1.5 \mathrm{~m} \text { in thickness) overlying limestone flags } \\
\text { (strong) and sandstone (moderately strong) inter-bedded with } \\
\text { variably weathered mudstones and siltstones (shale). }\end{array}$ \\
\hline
\end{tabular}

Table 3. Parameter values from SLOPEIW back analysis.

\begin{tabular}{|c|c|c|c|}
\hline Stratum & $\begin{array}{l}\text { Bulk unit } \\
\text { weight }\left(\mathrm{kN} / \mathrm{m}^{3}\right)\end{array}$ & $\begin{array}{l}\mathrm{c}^{\prime} \\
(\mathrm{kPa})\end{array}$ & $\begin{array}{l}\phi^{\prime} \\
\text { (degree) }\end{array}$ \\
\hline Ballast & 21 & 0 & 35 \\
\hline Embankment fill (granular) & 17 & 0 & 30 \\
\hline (cohesive) & 17 & 0 & 28 \\
\hline Glacial till (peak) & 19 & 0 & 33 \\
\hline Shear zone (post peak) & 20 & 0 & 22 \\
\hline
\end{tabular}




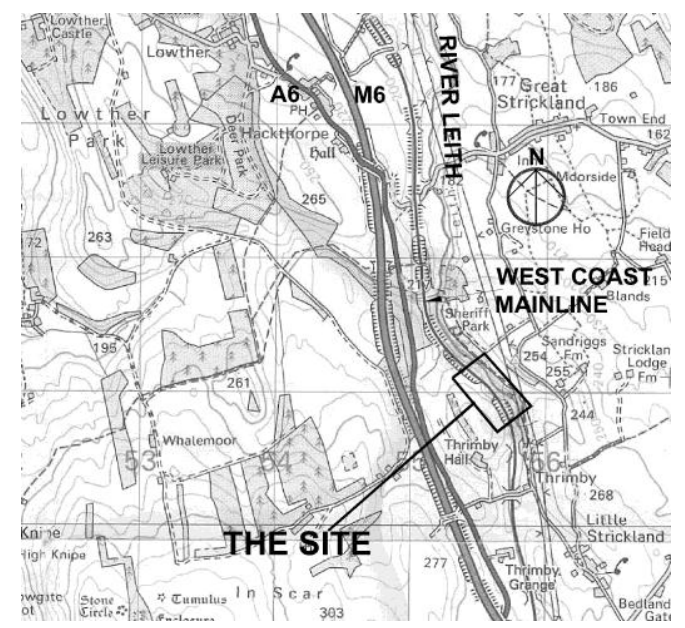

Figure 1. Site location plan.

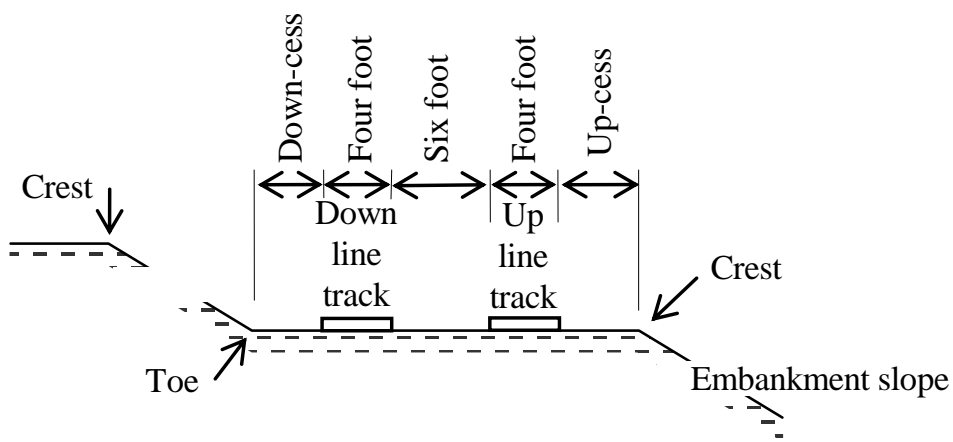

Figure 2. Terminology associated with Bessie Ghyll twin-track railway. 


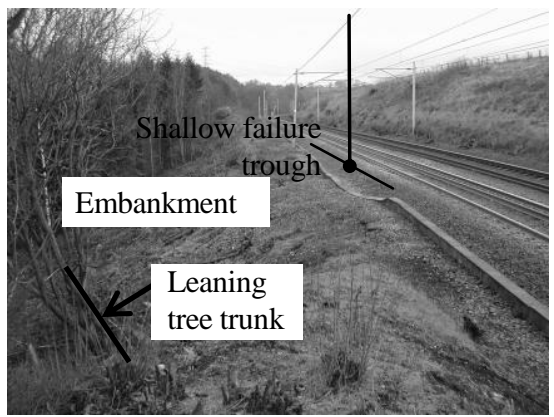

(a) Up-line slope.

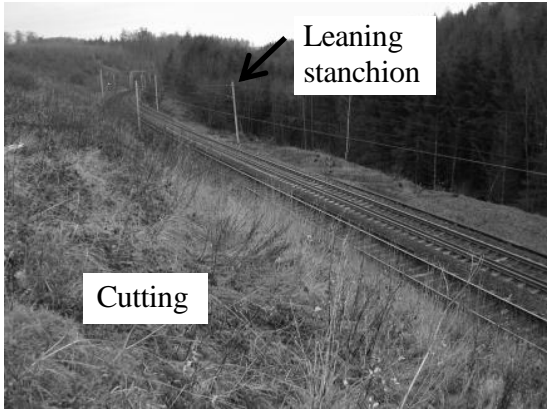

(b) Down-line slope.

Figure 3. Section of rail line requiring upgrade works.

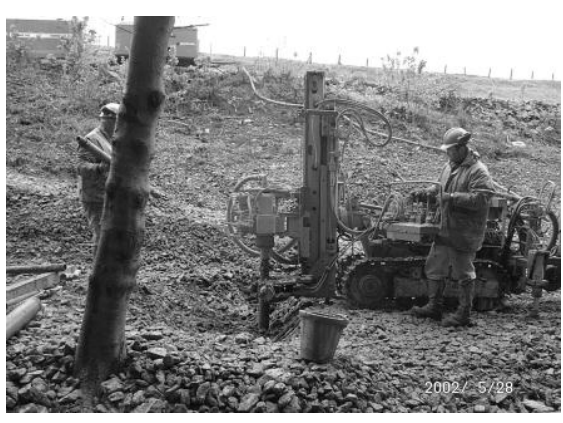

Figure 4. Mini track-mounted drilling rig operating on embankment slope. Note distorted tree trunk in foreground leaning down slope.

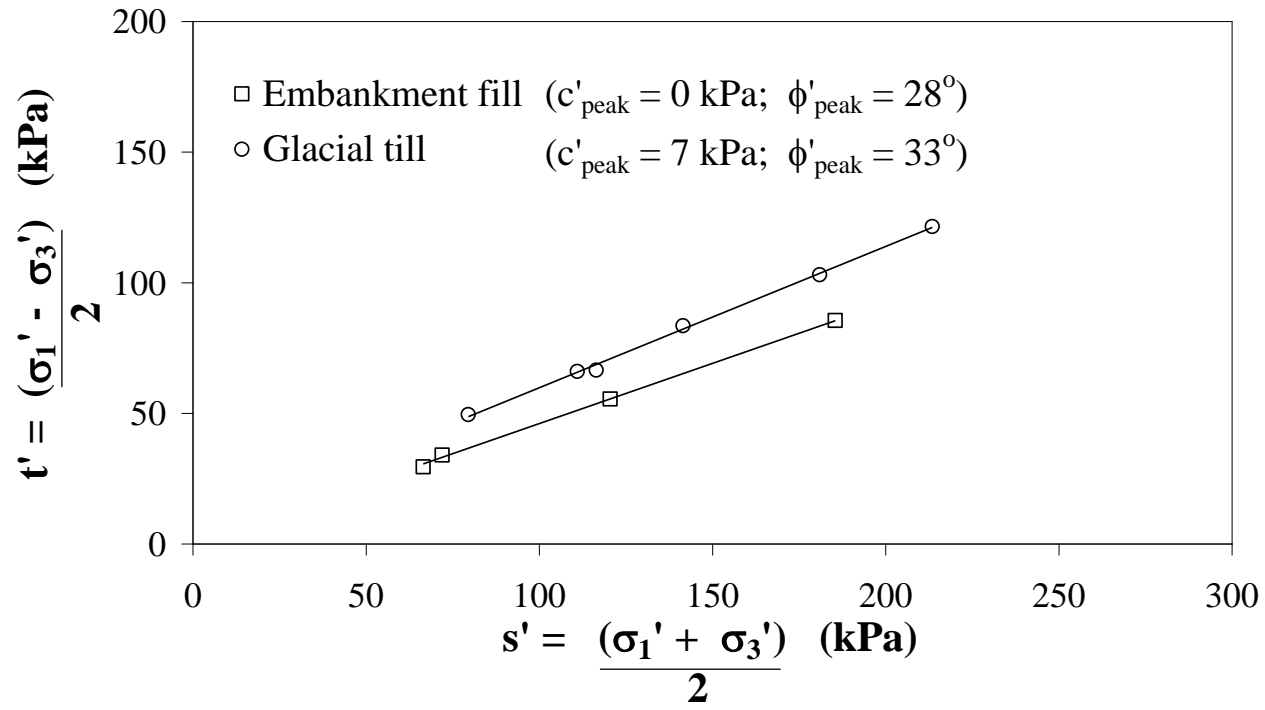

Figure 5. Peak stress path failure envelopes from CU triaxial compression tests. 


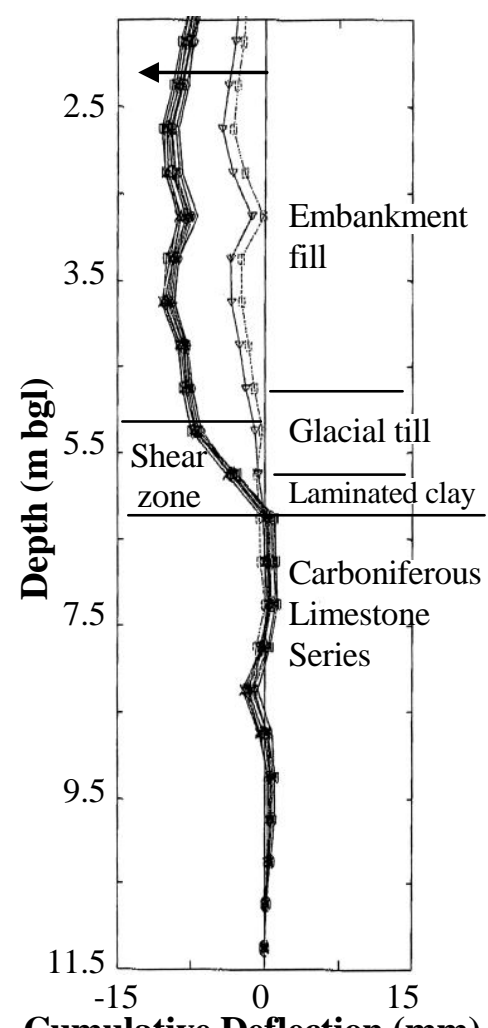

Cumulative Deflection (mm)
Initial 06 Apr 01

13 Aug 01

$\rightarrow 18$ Sep 01

+12 Oct 01

$\leftrightarrow 21$ Oct 01

$\leftrightarrow 29$ Oct 01

$x \rightarrow-x \quad 02$ Nov 01

$\leftrightarrow 13$ Nov 01

Q- $\rightarrow 22$ Nov 01

- 30 Nov 01

$\leftrightarrow 12 \mathrm{Dec} 01$

m.... $21 \mathrm{Dec} 01$

Instrument I01

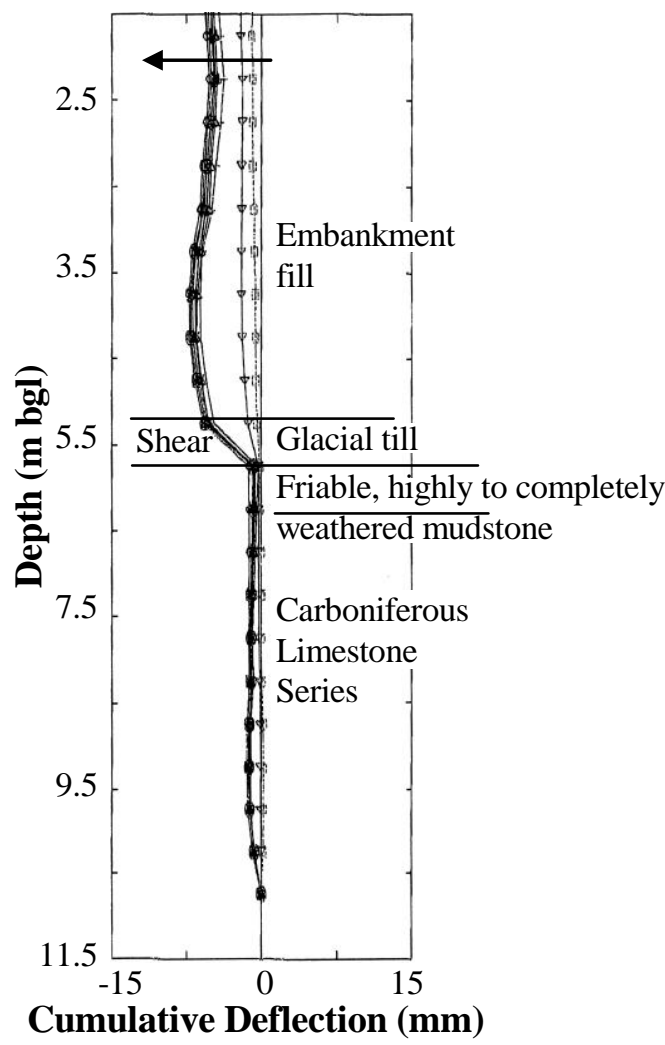

Instrument I02

(a) Cumulative deflection (April to December, 2001).

Figure 6. Inclinometer data for I01 and I02 located 4.2 and $6.4 \mathrm{~m}$, respectively, down embankment slope from near rail on Up-line. 


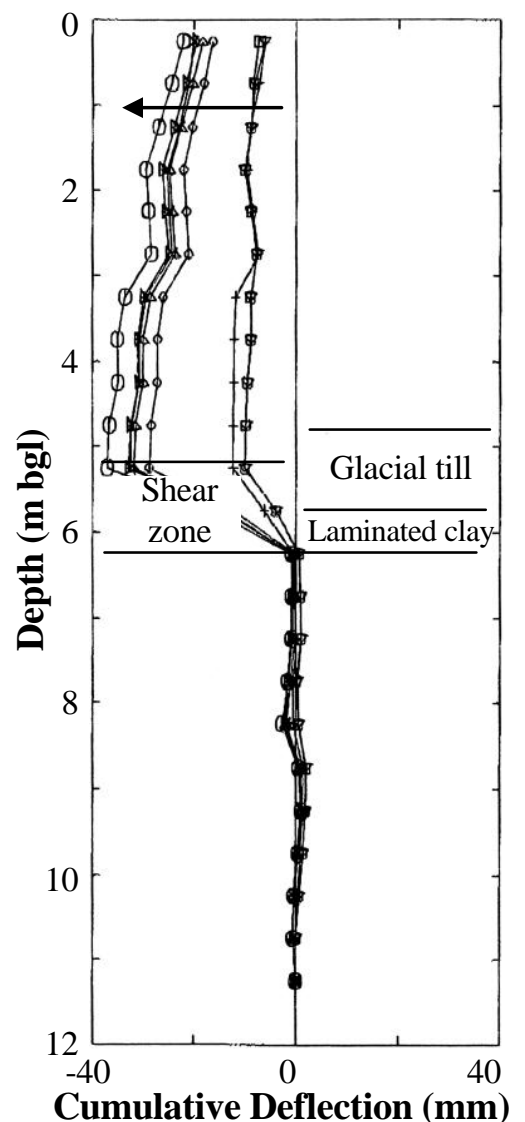

Instrument I01

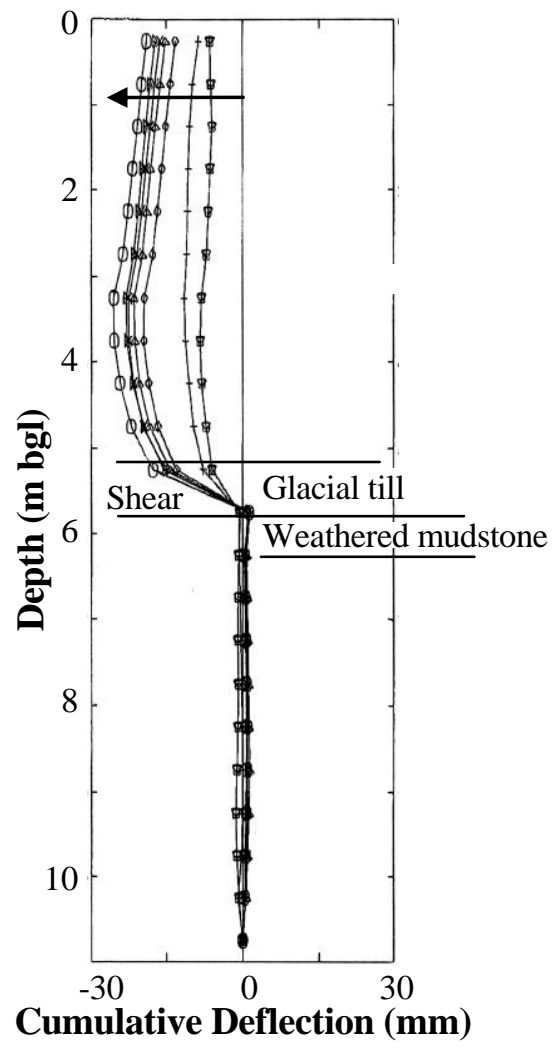

Instrument I02

(b) Cumulative deflection (April 2001 to March 2002).

Figure 6. Inclinometer data for I01 and I02 located 4.2 and $6.4 \mathrm{~m}$, respectively, down embankment slope from near rail on Up-line. 


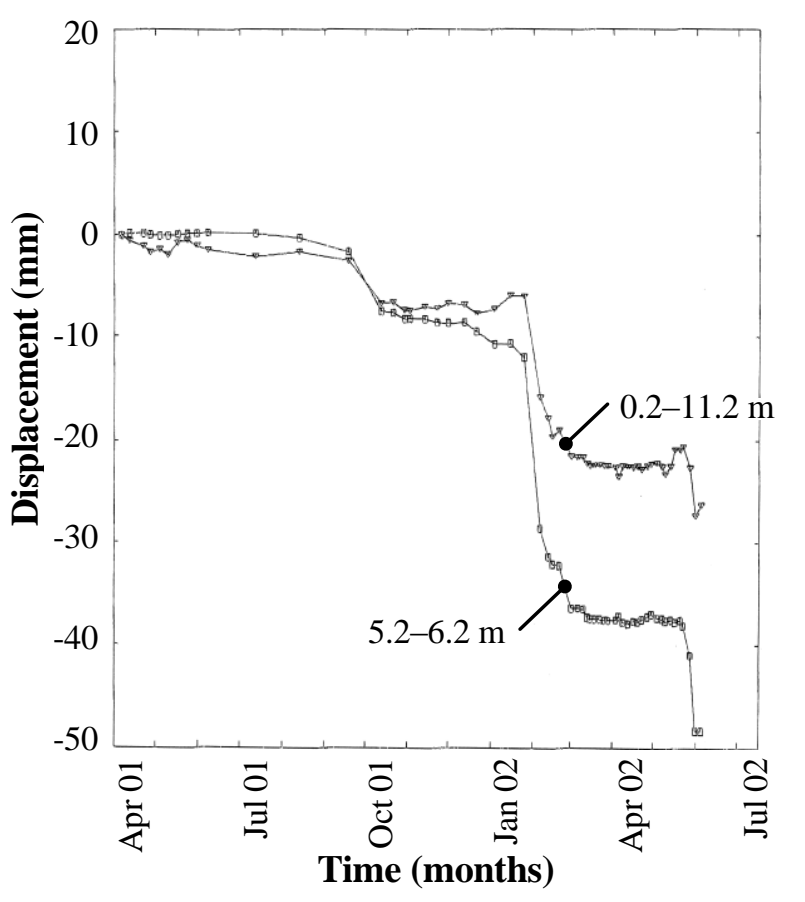

Instrument I01

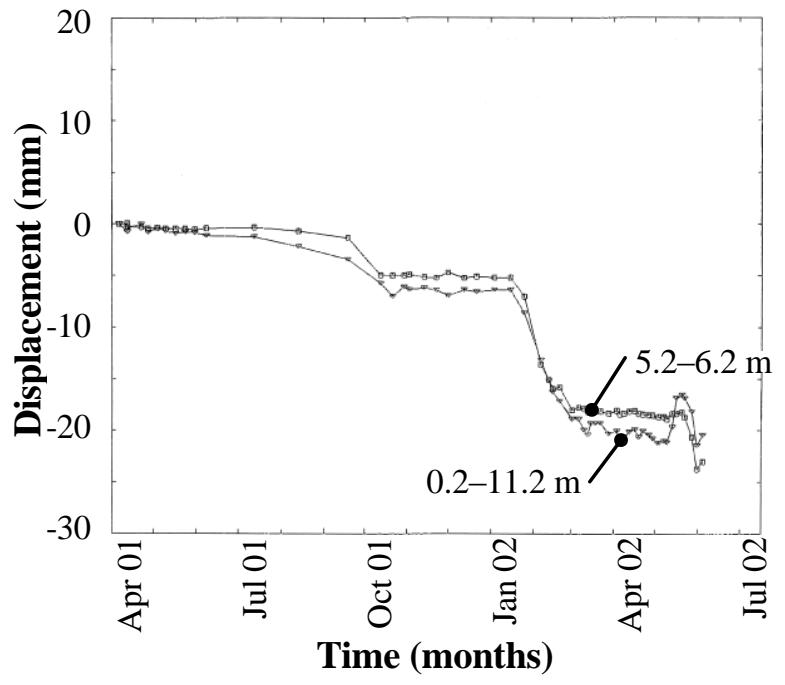

Instrument I02

(c) Displacement versus time.

Figure 6. Inclinometer data for I01 and I02 located 4.2 and $6.4 \mathrm{~m}$, respectively, down embankment slope from near rail on Up-line.

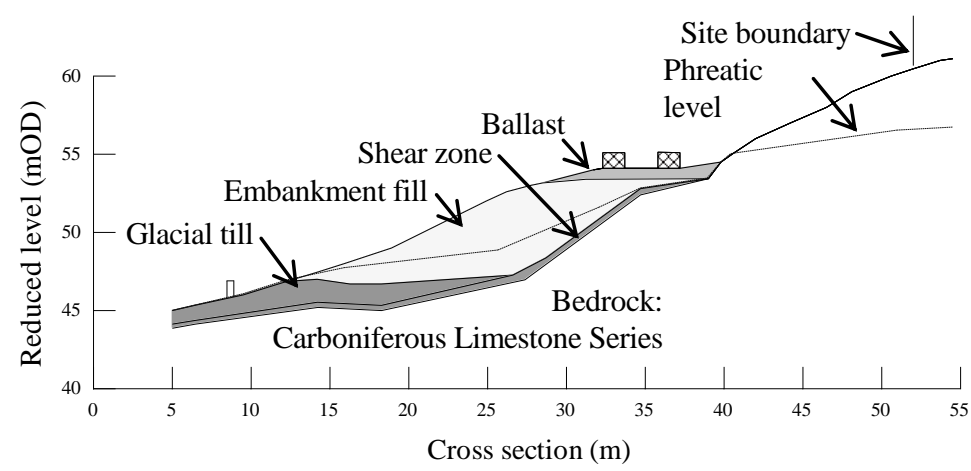

Figure 7. Critical embankment section. 


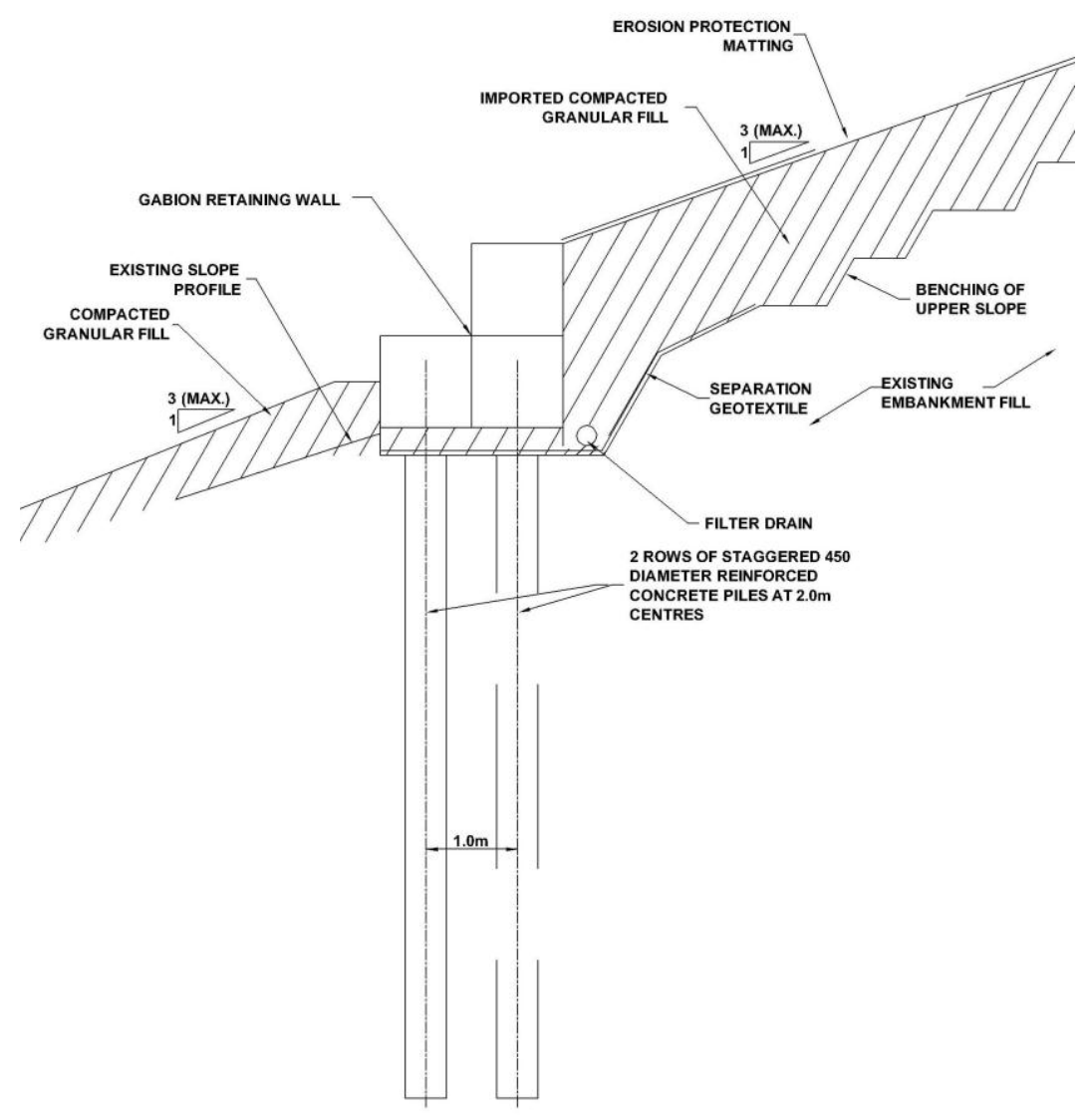

Figure 8. Stabilising pile and gabion retaining wall. 


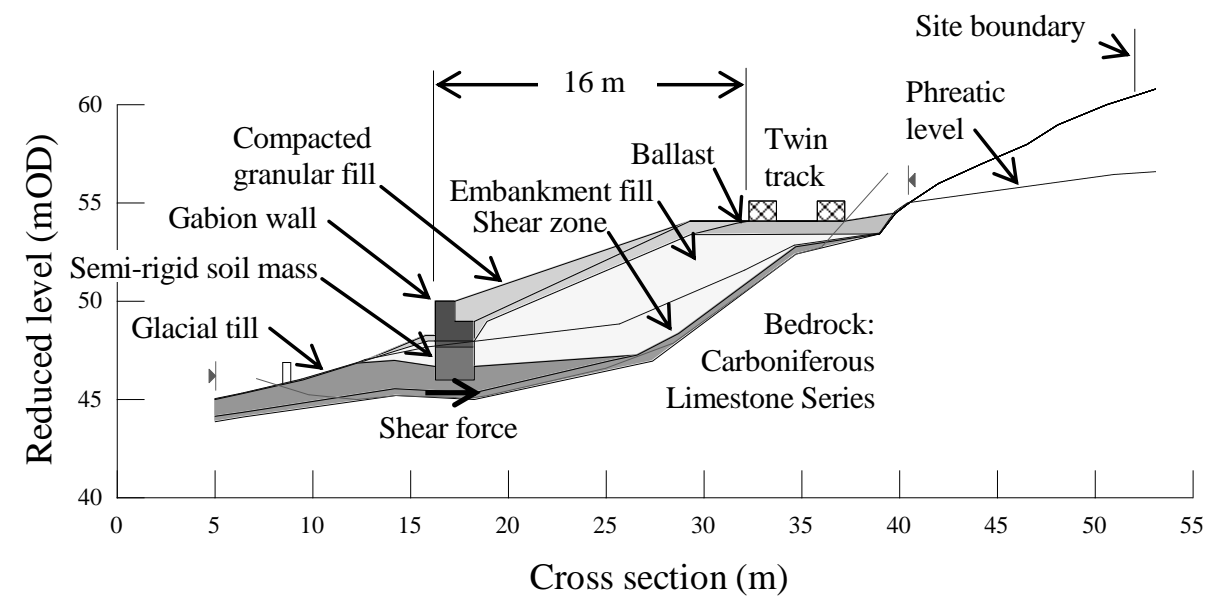

Figure 9. SLOPEIW analysis of upgrade works.

$\mathrm{F}_{\mathrm{v}}$ and $\mathrm{F}_{\mathrm{h}}$ : force redistribution from gabion wall in the longer term.

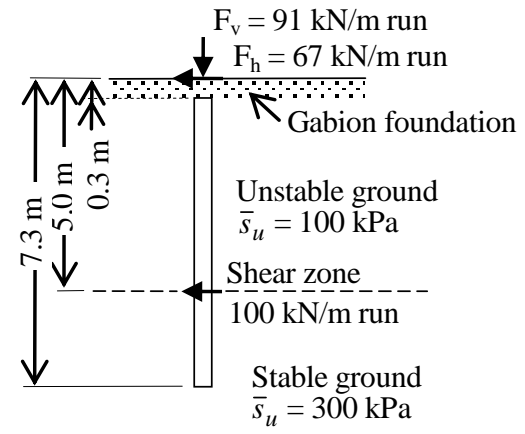

(a) System of forces.

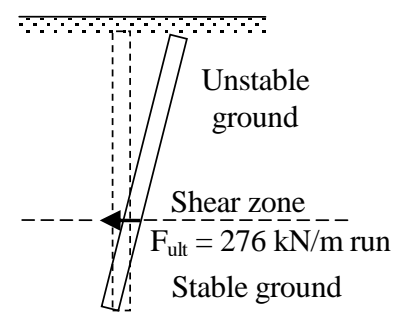

(b) Critical failure: Viggiani mode B.

Figure 10. Analysis of single stabilising pile for most unfavourable ground conditions. 


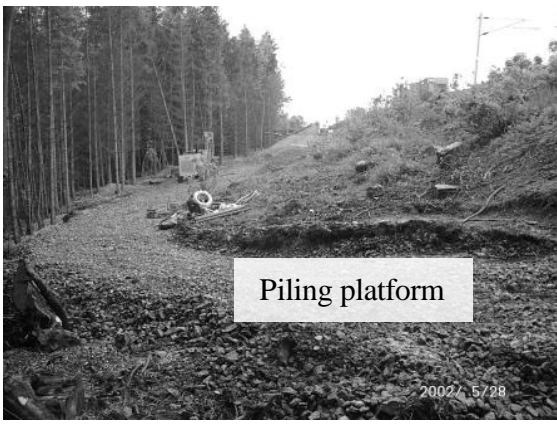

(a) Haul road to piling platform.

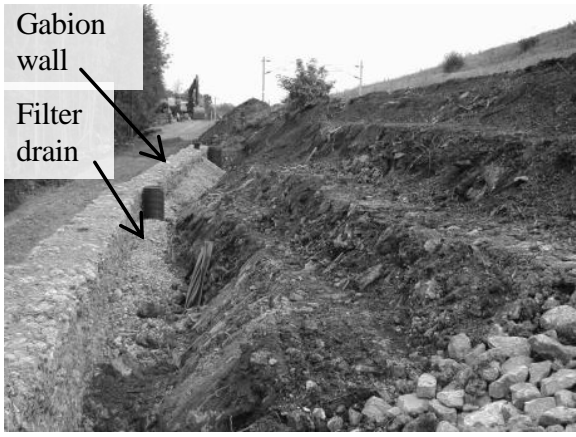

(c) Benching upper slope.

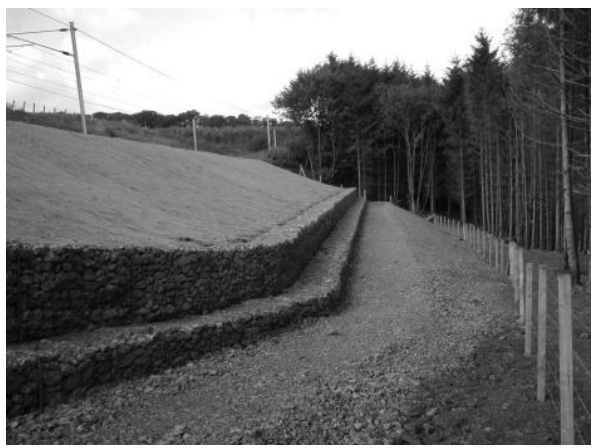

(e) Upgraded embankment slope.

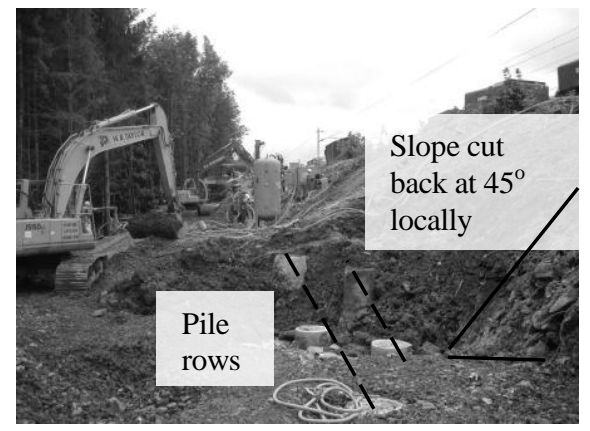

(b) Piling works.

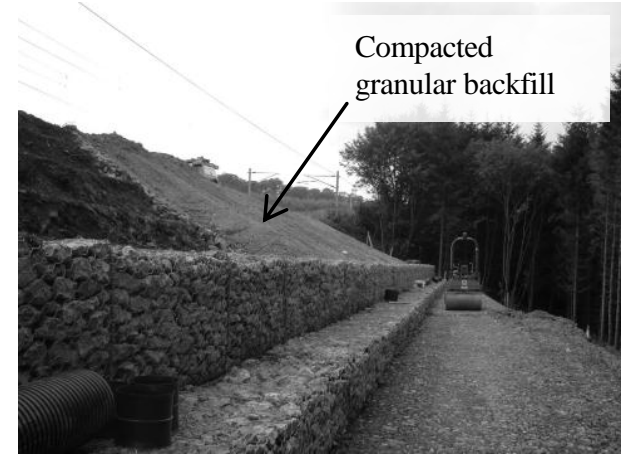

(d) Backfilling and regrading upper slope.

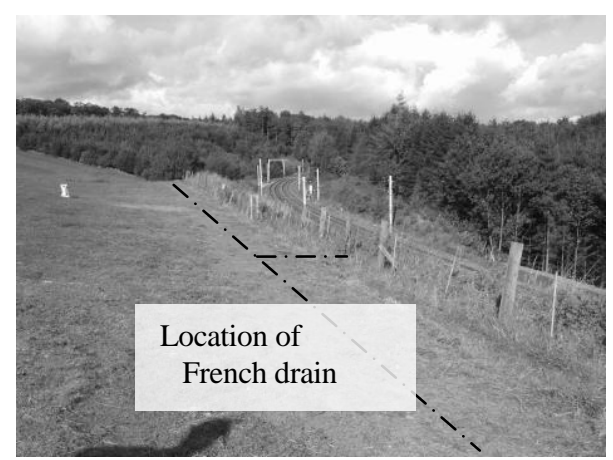

(f) View from crest over Down-line cutting.

Figure 11. Construction works. 


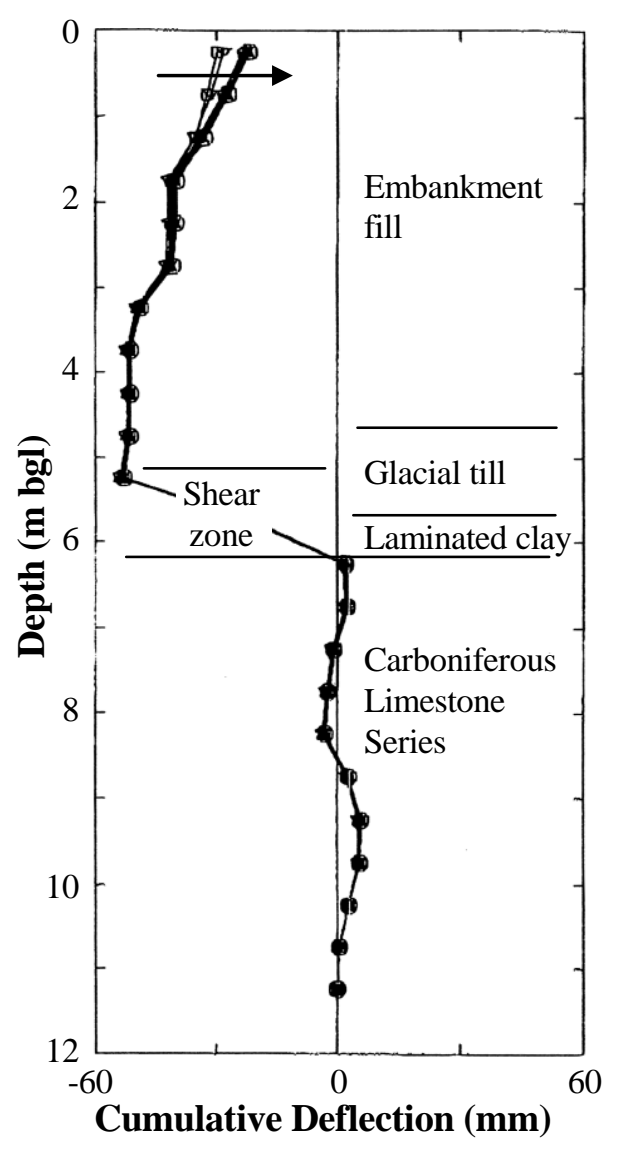

Instrument I01

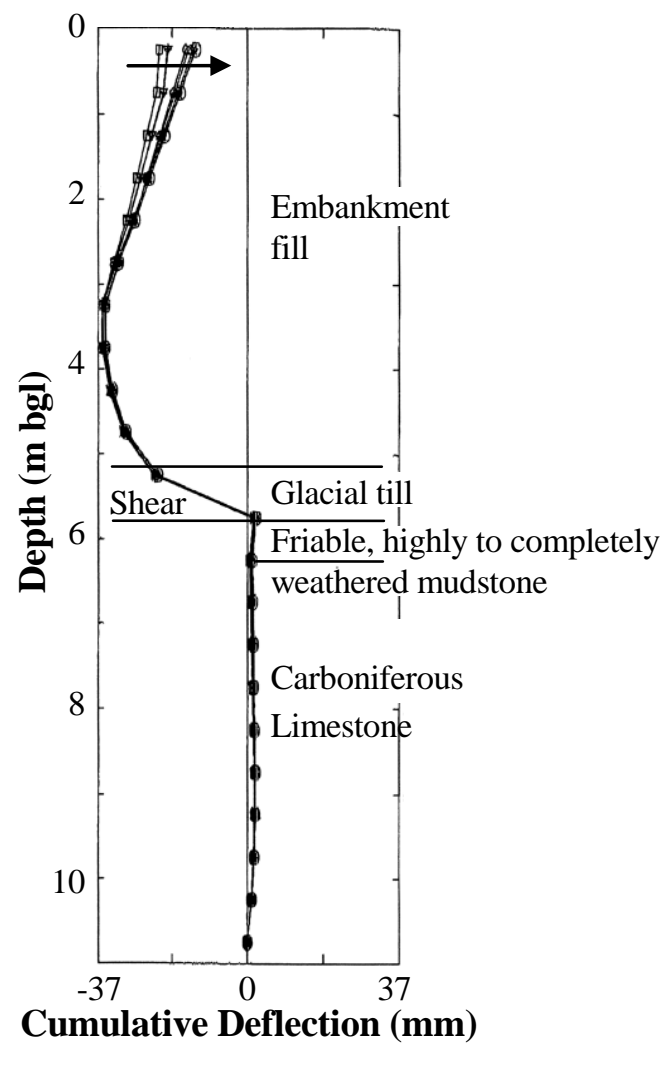

Instrument I02

(a) During construction works.

Figure 12. Inclinometer data for upper embankment slope. 


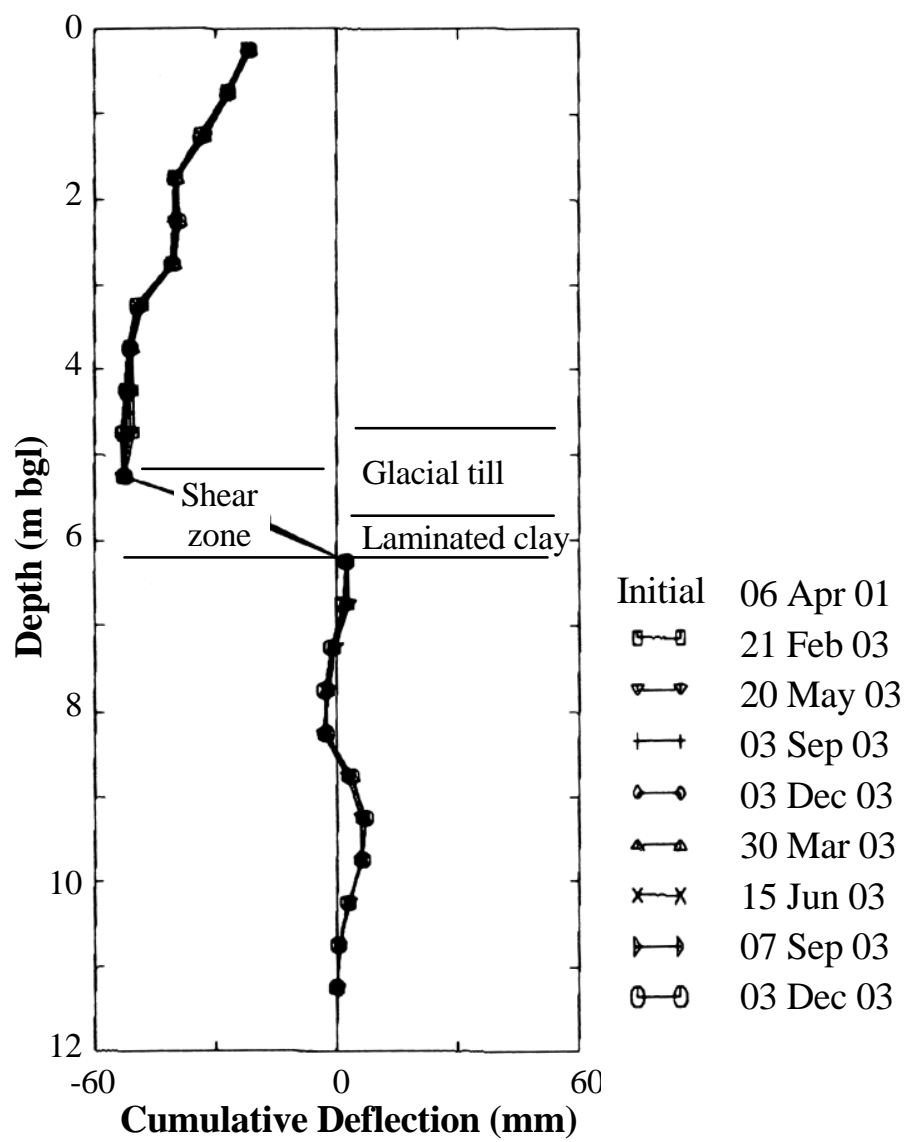

Instrument I01

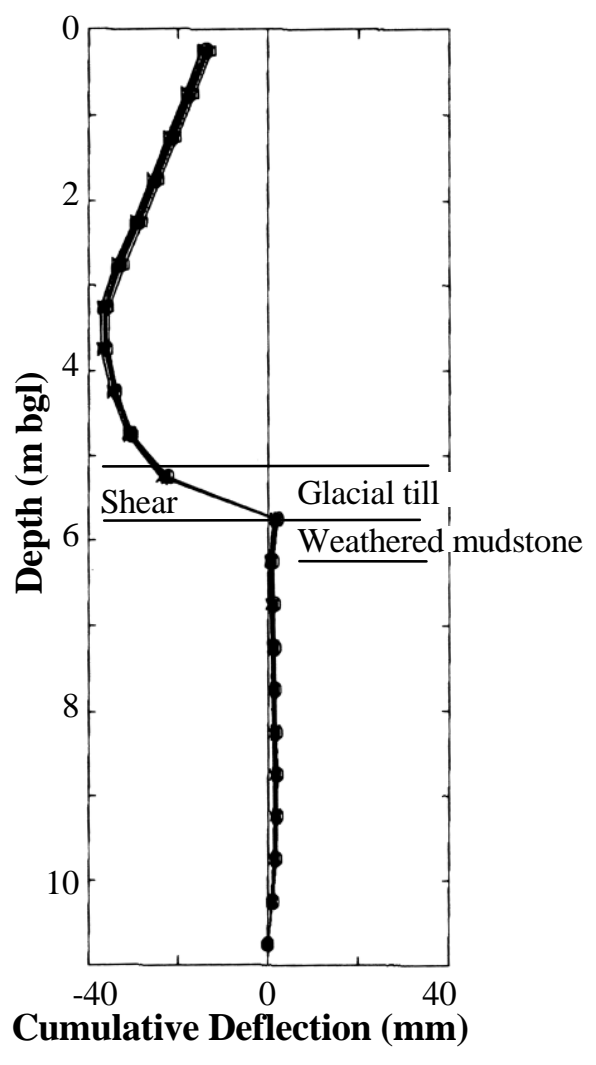

Instrument I02

(b) Post construction.

Figure 12. Inclinometer data for upper embankment slope. 